\title{
O TOQUE DO DESESPERO: UMA LEITURA PSICANALÍTICA DA PEÇA O PAI, DE AUGUST STRINDBERG
}

\author{
Estevan de Negreiros Ketzer \\ Doutorando em Teoria da Literatura na Faculdade de Letras (PUCRS) \\ E-mail: estevanketzer@ibest.com.br \\ Daniel Fraga de Castro \\ Doutorando em Teoria da Literatura na Faculdade de Letras (PUCRS) \\ E-mail: daniel.mitsein@gmail.com
}

São analisados alguns pontos na obra $O$ Pai de August Strindberg à luz da teoria psicanalítica no que diz respeito ao encontro das pulsões auto-destrutivas quando. Inicialmente, é realizado um breve apanhado das características do sentido trágico da antiguidade até o naturalismo e sua relação com o drama humano da modernidade, em que a subjetividade está implicada entre a sensação de frustração e de culpabilidade diante de seus entraves inconscientes. Essa demonstração encontra-se na via do silêncio, da espera ao próximo instante e de uma inarticulação da fala acerca do que a sensação privada que vem à tona. Eis que nos deparamos com aquilo que é para a psicanálise a pulsão de morte. Aqui a tragédia pela representação recria o momento do homem ao falar de si, provocando uma convulsão do nível afetivo mais interno.

Palavras-chave

Pulsão de Morte. Tragédia. Auto-Destruição. Psicanálise.
Are analyzed some points in the August Strindberg's play The Father in light of the psychoanalytical theory about the date of self destructives drives. Firstly, it's accomplished a brief summary about the tragic sense features of antiquity until the naturalism and its relation with the modern human drama, whose subjectivity is implicated between a relation of frustration and guilty in front of unconscious conflicts. This demonstration find it in the way of silence, from waiting to the next moment and an inarticulacy of the speech about what feeling comes to the surfacing. Here we are face with that means to psychoanalysis death drive. The tragedy using representation recreate the man's moment to speak of yourself, causing a convulsion from the affective level more intimate.

Keywords

Death Drive. Tragedy. Self Destruction. Psychoanalysis. 


\section{Sobre 0 Sentido Do Trágico}

Só se conhece uma vida, a sua própria.

August Strindberg

... tu somente és teu próprio inimigo.

Tirésias para Édipo

... aquele que por seu saber precipita a natureza no abismo da destruição há de experimentar também em si próprio a desintegração da natureza.

Friedrich Nietzsche

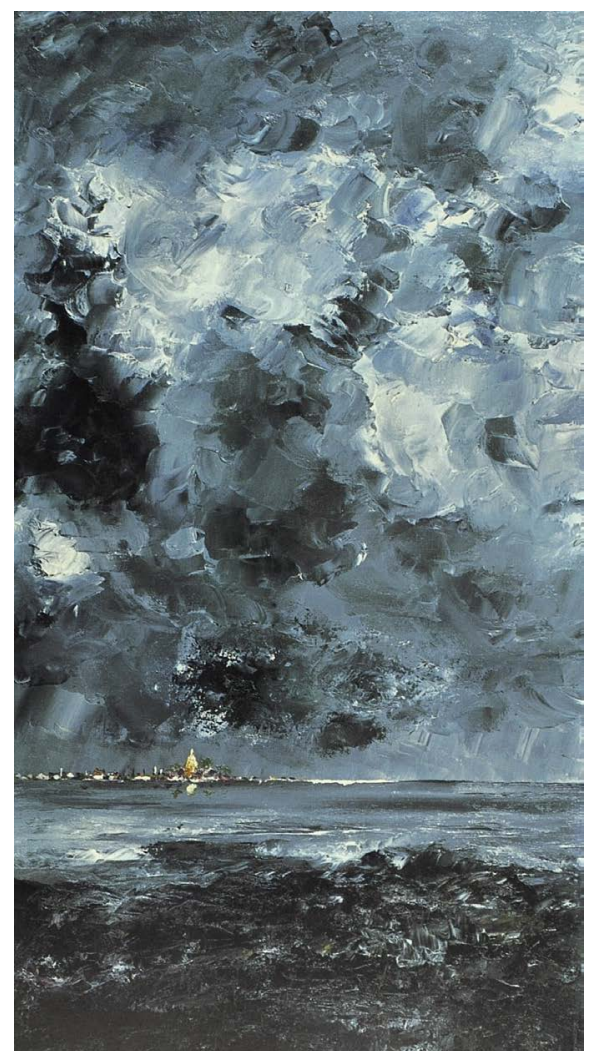

Fig. 1 - A Cidade (1903), Fonte: August Strindberg

August Strindberg (1849 - 1912) é filho de seu tempo. O autor sueco, entre suas muitas atividades como músico, pintor e químico foi com a dramaturgia que ele obteve reconhecimento. Suas peças tinha forte inspiração em elementos advindo do naturalismo.
Hauser (1982), aponta que o naturalismo como o resultado literário através da interação com a atividade científica a partir dos achados darwinistas, resultando em uma hiper-exploração do realismo para a compreensão dos comportamentos ocultos do ser humano. Em suas peças de maior importância 1 , ele demonstrou a habilidade da criação trágica, dizendo encontrar prazer em viver nos conflitos duros e cruéis da vida para saber alguma coisa sobre eles... saber alguma coisa sobre si.

Creio estar aqui um elemento importante na análise da peça $O$ Pai, escrita em 1887, pois ao dar a liberdade do autor em explorar e sentir elementos de cunho autobiográfico com um ímpeto destrutivo, como se tentasse a todo momento fomentando no discurso algo da via inconsciente, dos desejos sórdidos da sexualidade reprimida, da manipulação dos mais fracos, da acumulação de um grande capital financeiro, unindo a esses elementos um sofrimento atroz. Strindberg realiza com a escrita um ideal de modernidade: mostra seres humanos em conflitos mentais, perturbados entre as ações que crêem dominarem e aquelas que são impossíveis de conhecerem sem antes se machucarem profundamente. Cada personagem congrega em si um ponto cego de sofrimento, pois procuram não serem vistos como os outros os vêem.

$\mathrm{Na}$ arte dramática de Strindberg há uma plena consonância com a época de Freud, o discurso da psicanálise como um discurso que busca olhar para essa intimidade humana mais próxima da carne pelo desvelamento psíquico. Esse ensaio lança essas interrogações e apontamentos sobre a construção social do

\footnotetext{
1 Sobre a fase naturalista o autor apresentou o romance O Quarto Vermelho (1879) e as peças O pai (1887), Senhorita Júlia (1888) e Os Credores (1889). Compõe em 1902 a peça O Sonho, muito apreciada pelo pai do Teatro da Crueldade, Antonin Artaud. Nela Strindberg se aproxima de um expressionismo teatral, o que fez Artaud reclinar-se sobre sua encenação, devido às possibilidades de sensações e da descrição de estados de paranoia que o autor fora acometido. "O registro dos sentimentos que aí se acham traduzidos, reunidos, é infinito" (Artaud, 2008, p. 41).
} 
subjetividade na modernidade pelo resgate do humano que o movimento naturalista promoveu, inicialmente por Émile Zola, e em seu ápice pela recepção que Zola teve por Strindberg na França, entre 1888 e 1892. Sabemos das fortes intenções de Freud ao pensar o desenvolvimento das artes em seu tempo (Gay, 2012) e com ele a contribuição que a psicanálise da cultura pode fomentar com uma tentativa de compreensão de uma arte tão visceral quanto latente nos registros da mente humana.

\section{Breve Noção Do Trágico A Passagem Entre A Antiguidade} E A Modernidade

$\mathrm{Na}$ tragédia o homem quer conhecer a si próprio, mas só o pode fazê-lo diante do conflito com o mundo. Bornheim (2007) apresenta dois pressupostos para a existência da experiência trágica, o indivíduo, aquele que vive a situação, e o sentido de ordem que governa a realidade. O herói trágico quebra sua harmonia por realizar algum ato de desmedida (hybris) na qual obtém uma falsa noção de si, acredita que é mais ou menos do que o papel que o cosmos o designou. A sensação de conflito irreconciliável estabelece a tragédia de modo geral, mas este fenômeno estético desenvolveu-se no tempo e não se dá mais como na composição encontrada em peças como Édipo Rei e Antígona de Sófocles (1996) cujas convenções jurídicas humanas estão diante das entidades teológicas, com o homem no meio dessa disputa.

Contudo, Kathrin Rosenfield enxerga diferentemente o sentido corrente do homem na região da Ática do século $V$ a.C. A autora ob- servando com minúcia a ironia de Sófocles, reconhece este recurso estilístico como sendo o modo de apropriação do conhecimento na peça Édipo Rei. Este fato se dá quando os cidadãos tebanos são atingidos por uma crise na capacidade de lembrar seus próprios sofrimentos (Rosenfield, 2011). Eis que a figura de Tirésias parece já conhecer os malefícios da investigação edípica. A autora vai mais longe em sua crítica: busca insistentemente o traço do fracasso na figura de Tirésias, dito por ela um mal vate que tenta a todo o momento desmoralizar Édipo: "Tirésias já não exercia mais sua autoridade há tempos. Além disso, também no momento presente do drama. O senão oferece conselhos ou diretrizes dos seus vaticínios" (Rosenfield, 2011, p. 43). A questão parece muito nítida aqui: Édipo seria vítima de um grande complô no qual sua mãe se esforçaria por ocultar as provas do assassinato de seu pai, o rei tebano Laio. Tirésias tão pouco teria inteligência para resolver os desafios da Esfinge que ficaram a cargo de Édipo. Este fato contraria toda a possibilidade encantatória do mito tebano, uma vez que "em Édipo Rei, Sófocles parece ter-se empenhado em eliminar todas as conotações mágicas e sobre-humanas do saber mântico, mostrando, na figura de Édipo e na de Tirésias, uma mesma inteligência intuitiva" (Rosenfield, 2002, p. 100-101). A desconfiança de Édipo se dá no plano das pretensões políticas do velho Tirésias, mais do que em um especial chamado de Apolo. Tanto Édipo quanto Tirésias fazem uso aqui do verbo phronein que significa pensar de modo sensato. "[...] o Tirésias de Édipo Rei refere-se sempre a uma forma de conhecimento ou de reconhecimento que caracteriza o racionalismo contemporâneo e posterior aos trágicos." (ibidem, p. 104) A autora enfatiza a 
relação conflituosa entre os dois personagens e toda a trama que os une enquanto uma comunidade a compartilhar do sofrimento enquanto função do saber humano e disputarem o poder de Tebas (idem).

Esta breve consideração da autora traz algo do conflito contemporâneo em que a peça está fortemente implicada, uma vez que determinados discursos serão realizados com uma finalidade de vitória ou derrota por argumentos e não apenas pela profecia de um vate. Passamos a enxergar algo mais do que o cumprimento de uma profecia. O herói trágico é o investigador e ao mesmo tempo o culpado pelos crimes hediondos que assolam a cidade. Este fato levou seu cunhado, Creonte ao trono tebano. Nesse sentido, vemos um forte chamado à racionalidade nascendo no mundo grego, fato este que está em oposição à sensação dionisíaca que une homem a natureza. Nietzsche (1872/2007), em seu O Nascimento da Tragédia, enxerga nos gregos uma relação com a dor na manifestação da cultura. Habita aí um olhar para dentro do enigma da existência como o faz Tirésias ao mostrar o caminho de Édipo recaindo em incertezas: "Terrível coisa é a ciência, quando o saber se torna inútil" (Sófocles, 1996). Logo parece residir em um nível do esquecimento a verdade do conhecimento. Esquecer para um dia retornar à luz, como veremos em desenvolvimento ulterior. Esse problema do esclarecimento a posteriori trazido por Tirésias é mais embrenhado ainda na cultura grega, uma vez que é revelada a intensidade dos afetos em seu ato disruptivo, Aristóteles (1999) chamará de catarse esse certo método de reconhecimento e expurgo das paixões na alma dos homens. É próprio ao homem imitar (mimese) ações quando elas são inesperadas (idem). Ao fazer essa imita- ção o que é desconhecido passa a esfera do conhecido, mas este fato passa definitivamente à esfera do reconhecimento (anagnorises).

Observamos que este problema exaltado na esfera dos afetos trazem o problema de que o trágico não é uma mera constituição da obra, se não algo que o mais subjetivo e proibido dos desejos pode alcançar com a imaginação. Vemos mais claramente, com o advento da estética romântica, pela primeira vez, a imbricação essa alta performatividade dos elementos estéticos, com vista a uma sensibilização entre uma concepção de sujeito e os afetos que o percorrem. O sujeito entra no objeto e dele não sairá mais, pois o que importa é "deixar que esta obra carregue consigo a consciência de sua criação, ou seja, seu caráter reflexivo" (Duarte, 2011, p. 49). Tal caráter é parte de uma reflexão que a obra nos leva, como o caminho que se deseja de algum modo percorrer para conhecer melhor o desejo do caminho. Parece residir aí o caráter imprescindível que a querela das interpretações recai ao espírito trágico moderno em que a obra é parte do mundo. É na passagem para da obra estética para o homem de carne e osso que a arte dá um passo a mais sua relação com o mundo, não mais presa ao movimento estético que a promove, mas agora intencionalmente constituída de diferentes estratos de emoções que um sujeito contém dentro de si.

A psicanálise, desenvolvida no final do século XIX, trará essa discussão que desde Hegel pareceu mantida no mero encontro de um estranhamento com a obra. Freud tinha em mira olhar mais detidamente para essas emoções inconscientes como partes da obra de arte moderna, como bem ele o fez em seu artigo Delírios e sonhos na Gradiva de Jensen. 
Neste trabalho, Freud identifica o derradeiro problema do sujeito contemporâneo em seu fazer criativo ao "voltar-se para a questão da classe de sonhos que nunca haviam sido sonhados - sonhos criados por escritores imaginativos." (Freud, 1908/1974, p. 17) Este limiar da obra de arte como parte inquieta vida criativa de um homem também possui consequências para a construção psíquica humana, pois seu movimento é extremamente disruptivo e inovador, provocando um pensamento crítico acerca das intenções inconscientes do sujeito envolvido.

\section{Strindberg}

\section{E A Psicanálise: Limites}

A peça O Pai, de Strindberg, é permeada de registros pulsionais. Logo no começo o Capitão quer muito entender porque Nöjd, um funcionário de sua casa, se recusa a responder se é o pai de seu próprio filho. Esse diálogo inicial na peça, impregnado de acusações e de uma culpa sobre a paternidade, pois é como se o Capitão falasse de si, projetando sua angústia nos gestos de Nöjd. "Eu não tenho como decidir e, afinal, não me agradaria" (Strindberg, 2009 , p. 29). Se Nödj fez o filho qualquer um poderia ter feito, não havia exames de DNA na época de Strindberg, porém, tampouco há qualquer sinal de responsabilidade por parte do exame inquiridor dos personagens. Adolf, o nome do Capitão, insiste em uma teoria que discutirá com o Pastor: "O rapaz pode não ser lá muito inocente - não há como saber -, mas uma coisa é certa: se podemos atribuir culpa a alguém esse alguém é a moça" (ibidem, p. 30). O Pastor se exime de conferir uma sentença e puxa a conversa para a educação de Bertha, filha de Adolf com Laura. Por diferentes pontos de vista acerca do futuro da filha, Adolf sentese no direito de "decidir sobre a edificação do caráter" (ibidem, p. 30), pois ele vê todos os "esforços constantemente minados" (ibidem, 2009, p. 30). O Capitão quer ter o controle e o direito, quer algo da ordem da emergência do racional e o quer expressamente. O Pastor já mostra um certo desconforto com o meio, "você tem demasiadas mulheres por aqui" (ibidem, p. 30). A casa de Adolf, segundo ele mesmo, é como "estar na jaula de tigres" (ibidem, p. 30). É o saber sobre algo que não é da ordem do inteligível, mas que impele um gesto de agressividade profunda, como uma reminiscência arqueológica, um barulho estremecedor por detrás da estrutura. Os pensamentos parecem feitos de concreto, possuindo suposições bem firmes, irredutíveis, rígidas, como o Capitão os apresenta. Entretanto, Adolf os faz com tanta ênfase que nos leva a indagações igualmente importantes sobre seus estados afetivos mais remotos e latentes na peça.

Para pensar pensamentos Freud (1915/1974) desenvolveu em seu artigo $O$ Inconsciente, um modelo para a mente, por ele chamada de aparelho psíquico, pois contemplou defesas diante de atos considerados ameaçadores. A consciência, como a grande ponto do iceberg mental, nesse caso, só se refere àquilo que uma pessoa pode conhecer acerca de seus estados mentais e naquilo que ela pode encontrar em outra que igualmente também os possui. $\mathrm{O}$ autor segue para a argumentação do ponto de vista topográfico, isto é, aquele no qual a psicanálise pode examinar como os processos primários e secundários da psique. Nessa topografia do deslocamento e da condensação essas formações inconscientes representam um reinvestimento do 
desejo como uma "alucinação primitiva" (Laplanche \& Pontalis, 1982, p. 474), vislumbrando o campo de objetos idealizados. Posteriormente, a mente escoará de modo controlado, postergando o prazer na busca de outros caminhos possíveis, eis o processo secundário, o princípio de realidade.

Pensemos em como Adolf pensa a realidade, isto faz muita importância na trama, visto que pensar, no sentido que a peça confere, é impossibilitado pelo próprio Capitão. Há um investimento de relações com vista a um auto interesse de Adolf. O Pastor pergunta ao anfitrião o que ele quer da filha: "Quero que ela seja professora. Assim, se ficar solteira, pode tomar conta de si mesma e não terá mais pesares do que os outros professores que tem de dividir o salário com a família, os coitados" (Strindberg, 2009, p. 32, grifo nosso). Na intenção do Capitão uma filha tem de estar preparada à sua maneira, com a autoridade que lhe é devida e principalmente contra a opinião de sua esposa, Laura, que a quer ver artista plástica devido às inclinações pessoais da filha. Adolf deixa claro que a questão é financeira. Há algo que não se pode esquecer, que pode se perder se for desperdiçado, que pode colocar todo o sistema da vida em risco. Assim o dinheiro passa a representar um interesse que só a cabeça cheia de contas do Capitão poderia dar conta. O pensamento sobre a paternidade volta com mais força, pois Laura quer informações sobre a vinda de Nöjd, afinal o que será feito com o suposto filho dele?:

Laura - O veredicto está na lei! Capitão - Não consta na lei quem é o pai da criança.

Laura - Não, mas em geral é fácil saber.

Capitão - há quem diga que é impossível.
Laura - Que curioso! Então não há como saber quem é o pai de uma criança?

Capitão - Segundo dizem, não.

Laura - Que estranha! Mas então como o pai pode ter todos esses direitos sobre o filho da mulher? (ibidem, p. 37)

Só a responsabilidade ou a imposição da lei, mas isso pouco importa, já que não há dúvidas diante do casamento. Laura então faz a pergunta incômoda de toda a peça: "Laura Não há dúvida alguma?" (ibidem, p. 37) e a resposta infantil de Adolf recai em uma ingenuidade que só aumentam a tensão na cena. "Capitão - Espero que não! / Laura - Mas e se a esposa for infiel?" (Strindberg, 2009, p. 37). A esposa vai deixando no ar questões, quer por uma economia de palavras que acabam desvendando suas verdadeiras intenções, quer pela fragilidade emocional de Adolf, as dúvidas incomodam a atividade do pensar ao invés de fazerem pensar, deixarem marcas.

Freud (1920/1974), em seu Além do Princípio do Prazer, percebe que há na mente, além do prazer e da realidade como princípios básicos há o surgimento de uma pressão (drang) diante do perigo que pode colocar em jogo uma sensação de prazer, um medo, algo que pode entrar em perigo. A projeção de um medo serve para colocar à disposição do ser humano os motivos de seus sentimentos de modo disfarçado, pois trazê-los ao nível consciente é extremamente ameaçador. Assim, Freud se deu conta na prática clínica não ser possível obrigar ao paciente a confirmação da teoria do psicanalista, mas sim o material da mente deve ser repetido, pois é uma tentativa de lidar com o fracasso de sua sobrevida consciente. "Os pacientes repetem na transferência todas essas situações indesejadas e emoções 
penosas, revivendo-as com a maior engenhosidade" (ibidem, p. 34).

Repetir é um princípio importante que observamos fortemente em O Pai. Nela há um forte vínculo do indivíduo com seu passado que volta à superfície. Strindberg é fruto de seu tempo, tendo desenvolvido sua peça a partir de um forte sentimento de desastre psíquico em que projeções começam a ser desferidas contra determinados personagens considerados ameaçadores. Esse aspecto está fortemente relacionado às questões teóricas da tragédia moderna introduzidas por Raymond Williams onde a tragédia é "o conflito entre o indivíduo e as forças que o destroem" (Williams, 2002, p. $119)$, fato este que nos possibilita a forte aproximação de Williams enquanto um crítico literário que coloca os sentimentos humanos no centro de sua análise estética, pois enxerga certos pontos que confluem com a experiência interna individual. "A condição do desejo, inconscientemente, é a de ser sempre proibido" (ibidem, p. 129). E ao ser proibido a narrativa mostra um passo em direção ao real, aos pontos que as impressões iniciais não deixam claro. Esses pontos precisam ser esmiuçados, trabalhados, buscados em uma superfície mais profunda.

Os questionamentos do Capitão vão em direção a uma experiência de colapso pessoal. Surge a loucura em seus atos, não por negar que sua filha seja sua filha, pois, como se vê, é uma questão de combate contra sua esposa Laura. A loucura aflora quando seu discurso perde força de impacto sobre a realidade em que vive, quando Laura o convence de que ele não tem força suficiente para vencer. Ele está perdido, desorientado, enfraquecido, precisando de cuidados para discernir seu mundo psíquico, mas o que faz é justamente atacar um outro expressão de sua resistência interna. Quer acabar com sua ambivalência pelo discurso, tomando na razão a possibilidade de escapar de pensar. Diz o Capitão: "Você conseguiu despertar minhas suspeitas, e assim o meu juízo em breve estará turvado; meus pensamentos começam a perder-se. É a loucura iminente, que você tanto espera e que vai chegar a qualquer momento" (STRINDBERG, 2009, p. 66).

\begin{abstract}
Você não vê que sou indefeso como um garoto, não escuta que eu me queixo a você como se eu estivesse diante da minha mãe, não consegue esquecer que eu sou um homem, um soldado, capaz de amansar bestas e homens com uma simples palavra? Eu peço compaixão, como um doente; deito ao chão o símbolo do meu poder e grito para que me salvem a vida (ibidem, p. 70).
\end{abstract}

Essa estranha sensação interna do Capitão, identificado sua esposa como sua mãe, algo que livremente entraria na conflitiva edípica de Freud, mas ao invés da aceitação da limitação, da restrição Adolf entra em sofrimento, entra ainda que sua esposa minta, engane, não queria mudar a história, pois tem em mira a limitação psíquica do marido. A aceitação do papel de mãe que chega nas linhas seguintes fica clara a armadilha psíquica que Strindberg quer provar, quer provar um tanto esse limite desconhecido como voltando contra si próprio a impossibilidade mesmo de uma negação, o nada em primeira instância. Freud, em Além do Princípio do Prazer, percebe haver uma percepção de proteção contra sensações ruins. Habita na mente do criador da psicanálise, a possibilidade de existirem ações do próprio corpo - as pulsões -, nas quais haveria a possibilidade dessas forças serem de uma 
destrutiva, isto é, não estarem mais dirigidas ao próprio corpo, mas ao inorgânico, pulsões de morte, onde o "(...) instinto de retornar ao estado inanimado" (Freud, 1920/1974, p. 56).

O próprio organismo na sua complexidade estrutural possui uma energia que pode levar ao aniquilamento. Força de contradição interna do inconsciente, um princípio de investigação sobre sua essência e seu lugar no mundo, o que leva a, por vezes, ter de lidar com o lado obscuro de nós mesmos, tal como Édipo o fez: “(...) loucas palavras de sentido pouco claro. Como se o verbo, ao invés de iluminar o pensamento com uma luz apoliniana, levasse o ouvinte a mergulhar em trevas insondáveis." (Green, 1981/1994, p. 78). A punição de Édipo é a tentativa de sobreviver à culpa e aos achados de sua própria investigação e assim o capitão também o faz, desesperadamente, acabar com a suposta origem da sua loucura: $\left.1^{\circ}\right)$ tenta matar sua esposa uma vez que ela é a imagem projetada de si próprio; $2^{\circ}$ ) finalmente, vendo o fracasso nessa tentativa, ele tenta acabar consigo mesmo. Strindberg torna a nós espectadores partes dissociadas do Capitão.

Capitão - Antes, mais uma palavrinha sobre a realidade Laura, você me odeia?

Laura - Às vezes odeio! Quando você age como homem.

Capitão - É como o ódio entre as raças. Se é verdadeiro que viemos do maca$\mathrm{co}$, deve ter existido pelo menos duas espécies (Strindberg, 2009, p. 73).

A dualidade é marcante nessa cena. Determinar a verdade pela natureza. Isso recai ao século XIX e suas teorias racistas, princípio vivo no naturalismo, mas isso também recai a explicações exteriores, vindas de uma cientificidade que se aloja aos discursos de cada um dos personagens. Somente a teoria deixa de fora a prática cotidiana dos personagens. O Capitão também vai ceder ao desejo de Laura de vê-lo inimputável, ela assina a declaração de que o marido está loucopara ficar com a herança.

Talvez seja verdade que diante da culpa e do fracasso de lidar com as situações mais íntimas de sua natureza, ao herói só resta aniquilar-se. "O eu que almeja e deseja destrói o eu que vive; a rejeição da vontade é, todavia, igualmente trágica (...) a identificação da falsa sociedade - tortura, traição - como parte de nossos próprios desejos (...)" (Williams, 2002, p. 142). Reside aí a raiz que leva o ser humano à morte, sobretudo ao prazer em poder aproximar-se dela. Eis o fetiche à Thanatos, ou podemos pensar num encontro no qual, por fetiche, entende-se a utilização de um atributo que vincula poder a um objeto, poder de desligamento como "(...) fatores associáveis ao narcisismo e à destrutividade juntamente com o que decorre das fixações da libido de objeto" (Green, 1986/2010, p. 96). Ao se viver estáse o tempo todo a dar conta da morte, mas isso só é possível na medida do princípio de ligação com a vida, ao perder o sentido, pois a mão de Thanatos, a morte é mais fácil do que lidar com a vida, sobressai outra possibilidade de lidar com o objeto. "Como a parte odiada e destrutiva do eu que é dividida e projetada é sentida como um perigo para o objeto amado e, portanto, dá origem à culpa, esse processo de projeção também implica, de algum modo, um desvio de culpa do eu para a outra pessoa" (Klein, 1952/1978, p. 327). Base da identificação projetiva. E se inclui aí a culpa, pois permanece no personagem um eu agressivo, potencialmente ameaçador e destrutivo. Viver é encontrar essa intensidade monstruosa, quase uma antinatureza da natureza humana, 
próxima de uma natureza da natureza. O que seria repelido no ideal moderno passa a ser acolhido pela psicanálise, escuta de uma voz insana diante dos fragmentos de desejos. Ilusão que a tragédia nos traz, ilusão de poder se conhecer a ponto de apagar-se totalmente. Vida e morte são opostos que trazem de volta nossa sensação de solidão diante do mundo. "[...] a auto destruição é sua expressão fundamental, enquanto a hetero destruição constitui apenas uma tentativa de aliviar a tensão interna [...]" (Green, 1986/2010, p. 98). Para o psicanalista egípcio podemos observar a atuação da pulsão de morte diante de fortes depressões e psicoses que desintegram o Eu, fato esse que o trabalho de Freud em Além do Princípio do Prazer não deixara suficientemente claro. Em O Pai há um adentramento tão pesado sobre o eu que este não o suporta mais. Violência que o capitão comete contra Laura jogando a lamparina acesa, na loucura do ato imerso em um símbolo de destruição do foco em que ele mesmo perde o controle de si.

Amor e morte se enamoram, até certo ponto, mantendo em equilíbrio o eu. Green (1986/2010) problematiza esse masoquismo originário, em que as sensações catastróficas não poderiam estar ligadas, pois são anátemas. Clinicamente se pode dizer qualquer coisa em dependência do outro, mas a sensação sempre coloca o conceito de pulsão de mor$t^{2}$ freudiano na esfera de um desligamento do sujeito. Segundo Green (1986/2010, p. 100): "Inversamente, o objetivo da pulsão de morte é realizar, tanto quanto possível, uma função desobjetalizante pelo desligamento". Nesse discurso naturalista é do mais forte o direito de se servir de sua própria força do que da idéia de justiça e de caridade ao outro. A maior punição é a própria existência, pois habita uma profunda dor sem solução na vida. Como se viver fosse já, por si só, um ato de culpa, uma hostilidade que a cultura implica o psiquismo de cada sujeito. Nietzsche retoma essa ideia de um castigo, uma causa externa que mobiliza a pressão da dor e do sofrimento guardados, "a descarga de um afeto tônico, para apagar da consciência a marca da dor vivenciada" (Junior, 2006, p. 83). Essa emulsão de um afeto que não é consciente nos termos da filosofia até então empreendida pelo avanço da modernidade. Não por nada a crítica de Nietzsche se dirige com intensidade à teologia e às imagens ímpias de um cristianismo atento à vingança do próximo, sempre nutrida com afinco pelos fracos em relação aos fortes, tal como expressa atentamente a leitura de Nietzsche realizada por Müller-Lauter (1971/2009, p. 160-161):

(...) Deus deveria ser, para Lutero como também para Calvino, sempre um dominador cruel [Genealogia da Moral]: desse modo o cristão dirigia seus instintos e desejos para esse ser inventado. (...) "a profunda suspeita em relação à alegria do próximo, de sua alegria em tudo o que ele quer e pode" [Aurora], pois nesta também se anuncia o "tipo forte" [Genealogia da Moral].

O percurso desse ódio acumulado, tão presente na intimidade do que se indispõe ao diálogo, o que precisa ser vomitado, que não vê nem concebe solução. Eis o ressentimento marcado psiquicamente, essa marca que envolve o excesso de uma descarga de energia sem fim, uma "tentativa de anestesiar

\footnotetext{
2 Laplanche e Pontalis (1982) deixam clara a dificuldade do conceito, mas realçam as qualidades de uma força irreprimível, cuja ambivalência e a agressividade estariam relacionadas também ao caráter obsessivo e depressivo do sujeito.
} 
a dor por meio da intensificação de outra espécie de sofrimento psíquico, isto é, pelo auto-martírio da consciência de culpa." (Junior, 2006, p. 87) Nietzsche, profeta de Zaratustra, mas também do "mestre da grande suspeita" (Nietzsche, 1882/2012, p. 13), que corrobora o surgimento de um "médico filosófico" (Nietzsche, 1882/2012, p. 12) por vir.

Capitão - Ah, já chega; minha mãe e meu pai não me queriam! Eu nasci contra a vontade deles. Mas senti que eu me completava quando nós dois nos unimos, e assim você assumiu o comando; eu - eu, que na caserna comando a tropa - passei a obedecer suas ordens, cresci junto a você, admirei-a como se você fosse uma criatura com dons especiais escutei-a como se fosse um filho insensato.

Laura - É, foi assim mesmo, e por isso eu amava você como a um filho. Mas você via que sempre que a natureza de seus sentimentos mudava e você aparecia como o meu amante eu ficava tímida; e o seu abraço era uma delícia, mas depois eu me sentia arrependida, como se a vergonha corresse nas minhas veias. A mãe tinha virado amante! (Strindberg, 2009, p. 71)

Uma sensação ambivalente sem lugar, um incesto cometido na própria tábua que a imaginação provoca. Corpo alienado diante do abismo do ser, gerando a incapacidade de mudar sua história, embora seja a força de um sobre o outro que dá o tom da perturbação mental sofrida. Os problemas não cessam quando se quer. Não será desastroso ao Capitão ouvir isso da boca de sua esposa e se dar conta de que não há o que ele possa fazer a respeito? "A condição humana é trágica por causa da inserção do espírito na feroz e, em si mesma, trágica luta animalesca de sexo e morte" (Williams, 2002, p. 159). É um ponto derradeiro para a tragédia naturalista.

Aqui não mais cabe a razão humana lidar com o que acomete o corpo. O teatro de Strindberg traz elementos cada vez mais humanos, no sentido paulatino em que sua arte vibra a encetar um homem decadente, atravessado pelas pulsões e vítima antes de tudo. É nesse momento de vitimização da cena, um homem que se coloca na ambivalência dos gestos necessários para sua adultez, mas não a demonstra, pois toda a razão é um frangalho de emoções animalescas mal resolvidas. A história torna-se assim o arcabouço dos nós mal desenlaçados, de uma impossibilidade de experimentar a sensação de fracasso e de sobreviver a ela. Ao Capitão resta a camisa de força durante o terceiro e derradeiro ato do drama. Haverá limite melhor para a razão do que uma camisa de força? A mente consciente do Capitão entra em convulsão. Ele desmaia, restando a dúvida do que acontecerá quando despertar. Estará morto por completo? É o anúncio de um desmaio, um instante em que o desligamento se dá. Morta também é a nossa esperança de ver algo que sobreviva. Ele se deixou levar por um discurso que dentro de si estava mal assentado, mal incorporado como o seu discurso. Um impulso que luta contra si para não mais viver. Submissão ao outro. Com o medo de se desnudar, Adolf deixa de perceber que se desnudara demais sem o perceber. O Capitão cai na arrogância, marca do herói trágico, que não percebe a si próprio em meio ao redemoinho que o acomete, não percebe que sempre deixará rastros em sua história, pequenos brinquedos quebrados, esfacelados, que sempre estarão lá sem função com o restante do mundo. Eis o ápice da tragédia moderna. 
Considerações Finais: Um Percurso $\mathrm{Na}$ Desmedida

"Quem quer que possua algo que seja a um só tempo valioso e frágil, tem medo da inveja de outras pessoas, na medida em que projeta nelas a inveja que teria sentido em seu lugar" (Freud, 1919/1974, p. 299). Essa frase extraída do artigo $O$ Estranho, mostra o quanto a psicanálise está embrenhada na apresentação e sugestão para pensar formas estéticas anteriormente vista como formas ontológicas. Uma vez que o contexto do século XIX se mostrou favorável ao surgimento dos complexos psicológicos, também é neste século em que o ser humano pensa mais a respeito de si aliado a uma linguagem unida aos afetos, não o faz por uma mera analítica de termos opostos, mas faz com que os opostos se olhem embrenhados em uma relação de dependência muito difícil de encontrarem sua liberdade e pureza garantidas pelo conhecimento filosófico. Um ser singular que ao pensar transforma seu mundo de relações, mas teme a entrada densa nas questões que o comovem, estranha a realidade interna. São estes elementos destroçados pela mente consciente, mantidos pelo inconsciente. Eis que a psicanálise:

[...] está certa ao sustentar que todo afeto pertencente a um impulso emocional, qualquer que seja a sua espécie, transforma-se, se reprimido, em ansiedade, então, entre os exemplos de coisas assustadoras, deve haver uma categoria em que o elemento que amedronta pode mostrar-se ser algo reprimido que retorna (ibidem, p. 300).

Esse estranhamento é na verdade muito familiar. Quanto mais próximo de defesas primárias o sujeito recalca, mais o recalque utilizar-se-á de outras defesas primárias mais fortes para esconderem o que pode desmoronar.
Tentativa de extinguir a atividade projetiva causando a morte do objeto, matando o eu no ato e não no simbólico. A própria idéia da morte é intensa demais, como nos fala Freud, mas ela mesma pode ser o melhor caminho para reduzir o sofrimento psíquico quando se está perdido. Esse ponto contraria imensamente a possibilidade de lidarmos com a dor alheia, nos faz pensar que em muitos casos essa dor pode não ter uma resposta.

Na tragédia, é a dimensão da lei que parece forçar tanto as barreiras do silêncio para que o ser se desintegre. Ponto morto do lugar paterno, que mesmo lá não está, e quando está é um excesso, quando está é a imagem ilusória de um ideal paterno. Assim, Laura também não dá espaço para o pai, ele se coloca no lugar de filho o tempo inteiro. Foi no verbo que o conflito houve, por um breve momento, e é no verbo que a vida se particulariza estreitando-se na impossibilidade de ser com o outro, medo da diferença que implode a si mesma ao ser descoberta. Sua expressão não se estabelece na fala simplesmente, mas na possibilidade de revelação da verdade.

A arte de Strindberg representa justamente essa força do desejo que Freud faz questão de relacionar ao reprimido e, por sua vez, o fundante da fantasia. "Então, afinal de contas, é verdade que se pode matar uma pessoa com o mero desejo da sua morte!" (Freud, 1919/1974, p. 308). A sensação de retorno ao thanatos não é uma mera ilusão criada como artifício teórico, mas habita de uma porção humana que, por não estar contida pelo pensamento consciente, retorna à consciência na forma do reprimido - atos falhos, sonhos, transferência, formações reativas. Também aí aparece o destino (moira), cujo sentido revela esse contato com uma parcela desconhecida de nós mesmos. 
Há muito os clássicos se inclinam para compreender a falha trágica (amartia) como a deficiência que nos acompanha. A origem do homem é desconhecida, sendo por vezes o processo como se deu essa estrutura o desafio mesmo a ser sentido nos extremos da alma. E aqui se compreende melhor a ideia de um recalcamento e de uma pulsão de morte, pois o inconsciente ao recalcar pode fazê-lo com tanta força que se imiscua na própria reação de anulamento do ser, e talvez daí venha a hipótese de Green (1986/2010) acerca da identificação do eu com o funcionamento pulsional destrutivo como parte de um mecanismo regressivo de destruição do ser que percebe e coordena funções psíquicas.

Se tal representação (mimese) do olhar que recai ao homem conduz a uma tomada de decisão é o momento da culpa (eríneas) chegar ao homem, isto é, tornarem-no homem mais humano e cônscio de si, mas ele o faz com o sentimento de culpa. Também aqui está a relevância de se pensar acerca de valores tão explorados desde a Grécia antiga e retomados por Freud na Viena do século XIX. Um Édipo que, como Green (1981/1994) coloca, apresenta as relações dos homens com a natureza e com o conhecimento. Talvez daí também seja importante pensar a psicanálise como uma espécie de antropologia simbólica que busca não a abstração de uma suposta natureza humana, mas pensa os modos em que o homem habita o mundo por desenvolver um pensamento sobre a dinâmica de seus afetos. O lugar que a tragédia coloca a todos é de uma experiência que nasce antes da própria criança, pois é a experiência dos pais e o conflito pulsional que aí se intensificam, como aponta André Green (1981/1994). Eis assim o encontro com o Capitão, perdido no discurso. Ele é arrebatado pela desmedida (hybris), marcando seu psiquismo ao tomar assombro com seus (d)efeitos. Medos da revelação de um segredo que todos há muito tempo já sabem. Laura conhece o Capitão melhor do que ele mesmo, pois revela essa nulidade que ele já possui em si. Ao demarcar a pulsão de morte do marido ela revela o interstício de um segredo: uma vida mal vivida.

\section{Referências}

ARISTÓTELES. Poética. In: Os pensadores. São Paulo: Abril Cultural, 1999.

ARTAUD, Antonin. O Sonho de Strindberg. In: Linguagem e Vida. São Paulo: Perspectiva, 2008.

BORHEIM, Gerd. O sentido e a Máscara. São Paulo: Perspectiva, 2007.

DUARTE, Pedro. Estio do Tempo: romantismo e estética moderna. Rio de Janeiro: Jorge Zahar, 2011.

FREUD, Sigmund. (1908) Delírios e sonhos na Gradiva de Jensen. In: Obras Psicológicas Completas de Sigmund Freud. Rio de Janeiro: Imago, 1974, 24v. V. IX.

(1915) O inconsciente. In: Obras Psicológicas Completas de Sigmund Freud. Rio de Janeiro: Imago, 1974, 24v. V. XIV.

(1919) O 'Estranho'. In: Obras Psicológicas Completas de Sigmund Freud. Rio de Janeiro: Imago, 1974, 24v. V. XVII.

(1920) Além do princípio do Prazer. In:

Obras Psicológicas Completas de Sigmund Freud. Rio de Janeiro: Imago, 1974, 24v. V. XVIII. 
GAY, Peter. Freud: uma vida para nosso tempo. São Paulo: Companhia das Letras, 2012.

GREEN, André. (1981) Édipo, Freud e Nós. In: O Desligamento: psicanálise, antropologia e literatura. Rio de Janeiro: Imago, 1994.

. (1986) Pulsão de morte, narcisismo negativo, função desobjetalizante. In: $O$ trabaIho do negativo. Porto Alegre: artmed, 2010.

HAUSER, Arnold. História Social da Literatura e da Arte. São Paulo: Editora Mestre Jou, 1982.

JUNIOR, Oswaldo Giacoia Junior. Nietzsche como psicólogo. São Leopoldo: Editora Unisinos, 2006.

KLEIN, Melanie. (1952) Nota sobre alguns mecanismos esquizóides. In: Melanie Klein (org.). Os Progressos da Psicanálise. Rio de Janeiro: Jorge Zahar, 1978.

LAPLANCHE \& PONTALIS. Vocabulário da Psicanálise. São Paulo: Martins Fontes, 1982.

MÜLLER-LAUTER, Wolfgang. (1971) Nietzsche: sua filosofia dos antagonismos e os antagonismos de sua filosofia. São Paulo: Edusp, 2009.

NIETZSCHE, Friedrich. (1872) O nascimento da tragédia: ou helenismo e pessimismo. São Paulo: Companhia de Bolso, 2007.

(1882) A gaia ciência. São Paulo: Companhia de Bolso, 2012.

ROSENFIELD, Kathrin $\mathrm{H}$. Os caminhos "errantes" de Édipo. A sacralização do saber positivo. O mistério profano. Letras Clássicas, $\mathrm{n}$.
6, p. 79-98, 2002.

. Édipo Rei: tragédia da memória suprimida por um vate sem visões. Conexão Letras, Vol. 6, p. 41-55, 2011.

SÓFOCLES. Rei Édipo (trad. J.B. Mello e Souza). Rio de Janeiro: Ediouro, 1996.

STRINDBERG, August. Senhorita Julia e outra peças. São Paulo: Hedra, 2009.

WILLIAMS, Raymond. Tragédia Moderna. São Paulo: Cosac \& Naif, 2002.

Recebido em 13/05/2015 Aprovado em 18/06/2016 